Division of Geological \& Geophysical Surveys

PRELIMINARY INTERPRETIVE REPORT 1999-1

\title{
SIMPLIFIED GEOLOGIC MAP AND CROSS SECTIONS OF CENTRAL AND EAST ANCHORAGE, ALASKA
}

\author{
by \\ R.A. Combellick \\ Alaska Division of Geological \& Geophysical Surveys
}

\begin{abstract}
August 1999
THIS IS A PRELIMINARY REPORT OF SCIENTIFIC RESEARCH. IT HAS RECEIVED TECHNICAL REVIEW BUT HAS NOT BEEN REVIEWED FOR CONFORMITY TO THE EDITORIAL STANDARDS OF DGGS.
\end{abstract}

Released by

State of Alaska

Department of Natural Resources

Division of Geological \& Geophysical Surveys

794 University Avenue, Suite 200

Fairbanks, Alaska 99709-3645 


\title{
SIMPLIFIED GEOLOGIC MAP AND CROSS SECTIONS OF CENTRAL AND EAST ANCHORAGE, ALASKA
}

\author{
by \\ R.A. Combellick \\ Alaska Division of Geological \& Geophysical Surveys
}

\begin{abstract}
This geologic map and preliminary cross sections of central and east Anchorage, Alaska, are based on previous mapping, limited new photointerpretation, and available subsurface data. Using PC-based Geographic Information System (GIS) software, I updated and simplified the existing geologic map by adding recent fill deposits and combining units of similar genesis, composition, and age that are also recognizable in the subsurface. The GIS database consists of a USGS geologic map and over 4,000 geotechnical boreholes and water-well logs provided by numerous public and private sources.

Geologic cross sections were developed by using GIS to project graphic lithologic logs into scaled vertical layouts along selected lines. I manually correlated stratigraphic units using the log sections as guides. Identification and correlation of subsurface units are somewhat hampered by complex glacial geology, sparseness of deep boreholes, and significant variation in lithologic descriptions among many drillers. Although these limitations result in some generalized, undifferentiated geologic units, the differences among interpreted units are of the level desired by the geotechnical user community for highlighting engineering and seismic behavior.
\end{abstract}

\section{INTRODUCTION}

Existing geologic maps and derivative maps at various scales have been used extensively for planning and resource evaluation in the Anchorage area (Cedarstrom and others, 1964; Dobrovolny and Schmoll, 1974; Miller and Dobrovolny, 1959; Schmoll and Dobrovolny, 1972a, 1972b, 1973, 1974; Schmoll and Emanuel, 1981; Yehle and others, 1990, 1991, 1992). A limitation of these maps is that they do not provide information on the thickness of surficial deposits or the nature and variation of underlying materials. This information is critical for mapping earthquake hazards, such as ground-failure potential and site amplification. Subsurface data collected since the 1950s, particularly from deep boreholes and wells drilled for construction of large buildings, allow interpretation of subsurface stratigraphy and construction of detailed cross sections. Cross sections prepared by Updike and Ulery (1986) show, for example, that the Bootlegger Cove Formation (BCF) contains several major facies with highly variable physical properties. They also show that relatively thin $(<10 \mathrm{~m})$ glaciofluvial sand and gravel at the surface are locally underlain by sensitive facies of the BCF that could cause catastrophic failures during earthquakes, as occurred during the great Alaska earthquake of 1964. A single east-west cross section (Schmoll and Barnwell, 1984), extending east from southern downtown Anchorage, shows how the sedimentary section thins and changes character eastward above a west-sloping bedrock surface.

Presently the only earthquake-hazard map publicly available for Anchorage is a ground-failure susceptibility map produced by Harding-Lawson Associates (1979) for the Municipality of Anchorage. This map shows relative earthquake hazard and communicates effectively to a nontechnical audience the idea that the earthquake hazard is greater in some areas than in others. It has provided a reasonable basis for community planning and development of earthquake-related zoning regulations in the Anchorage area. The Harding-Lawson map is based on surficial-geologic 
maps available at time of preparation and on damage patterns resulting from the 1964 earthquake. Instability of subsurface deposits is accounted for in a general way but is based on sparse subsurface data and known behavior of some deposits during the 1964 earthquake. The limitations of the 1979 map for assessing subsurface geologic conditions were recognized in the report that accompanied the map: "The need for subsurface data in all of the lowland areas underlain by unconsolidated sediments is the most important data gap. Plans should be developed to acquire existing as well as future subsurface data and incorporate it into hazards maps."

In the interest of providing an improved subsurface framework for earthquake-hazard maps and other potential uses, the Alaska Division of Geological \& Geophysical Surveys (ADGGS) began compiling borehole and well-log data for Anchorage in the early 1980's. Prior to the advent of Geographic Information Systems (GIS), the data were kept mostly in paper files; geologic correlations were done manually on large sheets. The first product of this database was an engineering-geologic map and cross sections of southwest Anchorage (Updike and Ulery, 1986; fig.1).

With the goals of (1) completing data compilation and geologic cross sections for the entire Anchorage area and (2) making the data more easily accessible and usable, ADGGS developed a GIS database containing borehole data, water-well logs, and maps. The GIS database provides the capability of automatically displaying borehole locations and attributes in relation to topography, geology, or any other mapped features, and for quickly retrieving and displaying borehole logs in cross-section layout. Digital data compilation was initiated first for the central and east Anchorage area (current project area) so that cross sections could be completed there to supplement those already prepared by Updike and Ulery for southwest Anchorage.

This preliminary report describes the methods and results of subsurface data compilation and the preparation of a geologic map and cross sections for central and east Anchorage. Although the locations of most boreholes and water wells compiled by Updike and Ulery in southwest Anchorage have been digitized (fig. 1), the borehole data have not yet been entered in the database. Completion of the database for southwest Anchorage and the continuation of cross sections across the entire city are among the goals of the work to follow. A final report will be prepared that will include a revised geologic map and cross sections that span the entire city .

\section{SUMMARY OF GEOLOGY}

The geology beneath Anchorage is a product of the complex interplay of glacial, fluvial, stillwater, and colluvial depositional processes during the late Pleistocene and Holocene epochs. The resulting sediment wedge ranges in thickness from zero where it abuts metamorphic rocks of the Chugach Mountains to the east at an elevation of about 1,000 ft $(300 \mathrm{~m})$, to about 1,600 $\mathrm{ft}(500 \mathrm{~m})$ thick where it overlies Tertiary sandstone beneath Pt. Campbell in the westernmost part of the city.

During late Wisconsin time, glacial ice advanced over the Anchorage area several times from the northeast, northwest, and south, first leaving deposits of hard till of widely varying thickness over the bedrock. As these glaciers retreated, they left complex deposits of washed ice-contact sediments. Later advances did not cover the entire lowland area with glacial ice and instead impounded water that at times was turned brackish by contact with marine waters of lower Cook Inlet. Sediments that filled this basin grade from relatively clean glaciodeltaic sand and gravel along the basin margins to thick deposits of glacioestuarine silt and clay in the basin interior, part of which underlies downtown Anchorage. Sensitive clays of BCF, notorious for the massive ground failures that occurred during the great earthquake of 1964 (Mw 9.2), were deposited in this glacioestuarine environment about 13,500$15,000{ }^{14} \mathrm{C}$ yr ago (Reger and others, 1995).

The last major glaciation to affect the Anchorage area was the Elmendorf advance from the northeast, about $13,500{ }^{14} \mathrm{C}$ yr ago. This advance reached as far as Elmendorf Air Force Base, about 3 $\mathrm{mi}(5 \mathrm{~km})$ northeast of present-day downtown Anchorage. Gravelly outwash from this advance 


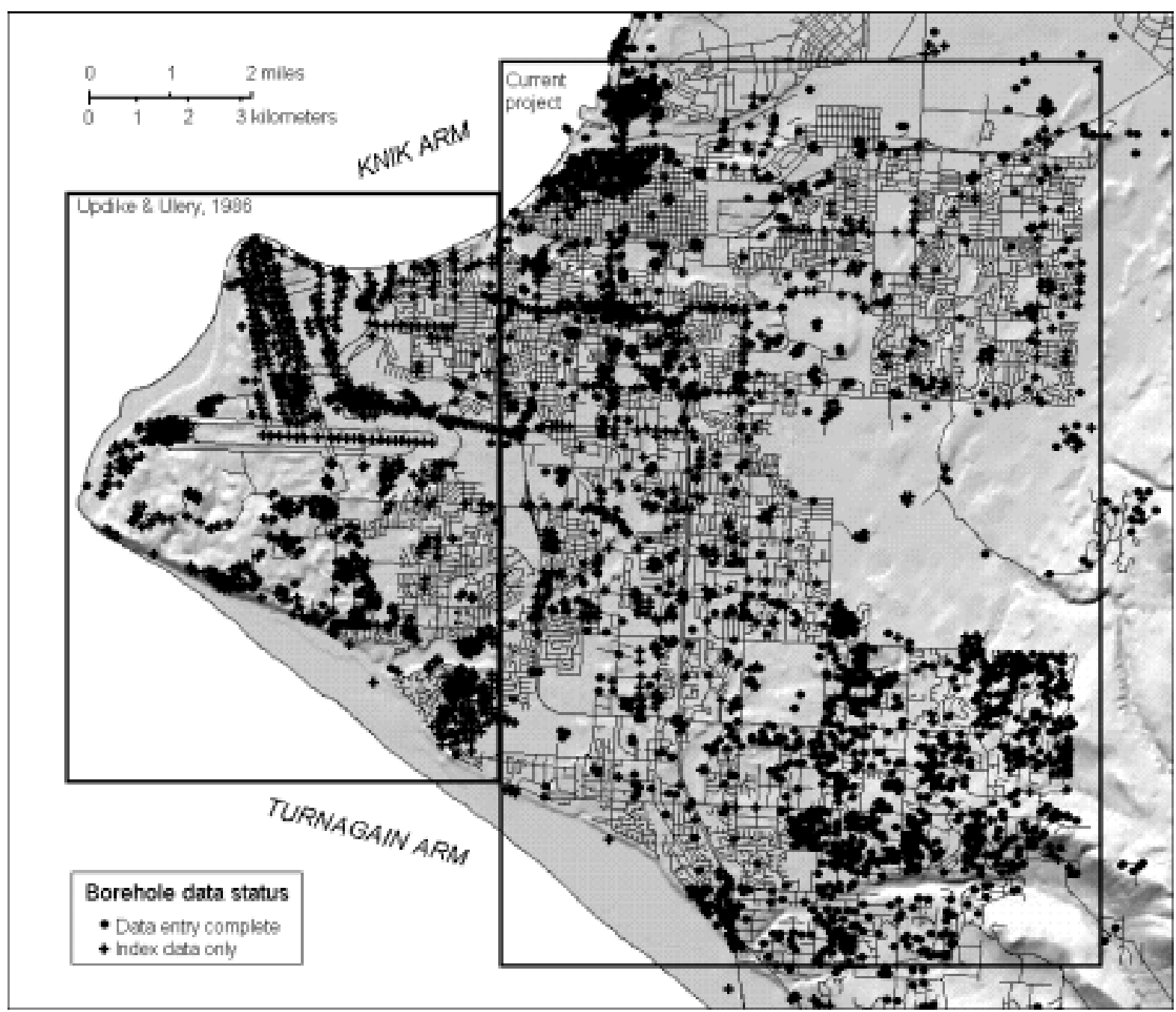

Figure 1. Map of Anchorage, Alaska, showing project areas and status of borehole database.

blankets most of northern Anchorage, including the downtown area, to a thickness of up to several tens of feet.

During Holocene time, the Anchorage lowland was dissected by several small streams, which left alluvial fans along the mountain front and partially filled their incised valleys with alluvium. Along sea bluffs and stream banks, particularly where fine sediments of BCF are exposed, numerous slope failures produced large slide deposits. Many of these slope failures, like those in 1964, were probably induced by earthquakes.

Knowledge of the distribution, thickness, and character of these subsurface deposits is important for understanding the likely physical effects of future earthquakes in the Anchorage area. These properties affect both the amplification of seismic motion and the types and severity of earthquakeinduced ground failures. 


\section{METHODS}

\section{Data compilation}

Map data compiled for the GIS database include five 1:25,000-scale U.S. Geological Survey (USGS) topographic quadrangles and a carefully digitized version of the most recent geologic map of Anchorage (Schmoll and Dobrovolny, 1972a). The topographic maps were digitally trimmed and spliced seamlessly together, then geographically registered to provide an accurate base map for the geology and for digitizing borehole locations. The database was originally established on workstation-based GIS but was moved early in the project to more user-friendly desktop GIS. Conversion of database elements from one system to another is relatively straightforward.

All geotechnical borehole data and some water-well data were obtained in paper form from public agencies and private companies that have drilled significant boreholes in the Anchorage area since the late 1950s. The U.S. Geological Survey provided most of the water-well data in digital format from its Groundwater Site Inventory System. The water-well database is not complete, particularly for wells drilled since 1988, because staffing reductions at both the federal and state levels have greatly slowed data entry. Manual data entry of hundreds of water-well logs was beyond the scope of this project; priority was given to manual entry of geotechnical borehole logs and a few selected deep water-well logs.

All borehole and water-well data reside in a relational database, created and maintained using a popular PC-based program. Although the GIS software is separate, an Open Database Connection (ODBC) allows the borehole data files to be an active part of the GIS, thereby facilitating corrections and updates. The borehole database includes separate tables for unique types of information, related by project and borehole index numbers as indicated in table 1 .

The locations of all indexed boreholes and water wells in central and east Anchorage are shown on sheet 1 . A borehole or well is indexed if the database contains at least a location and basic reference information that is keyed to a filed hard copy of the data. Table 2 shows the current status of data entry by type. Data entry is reasonably complete in the area of sheet 1 for all known geotechnical boreholes of $50 \mathrm{ft}$ or greater depth, and for all available digital water-well data from wells $100 \mathrm{ft}$ or greater depth. In addition, data have been entered for many shallower boreholes and water wells where needed for geologic interpretation. Because table 2 represents the entire Anchorage database, most of the indexed holes for which downhole data have not been entered are in southwest Anchorage outside the area of sheet 1 . The remainder of downhole data not yet entered are for shallow holes and cone-penetration tests. For 69 of the water wells, water levels are available but lithologic logs are not. Upon completion of the database for southwest Anchorage, a separate data release will provide an index map and logs of nonproprietary boreholes and wells; these data will also be made available in digital formats.

All borehole and well-log data compiled for this project use English units of measure. Although it is possible to convert all data to metric units, this would be inconvenient for the primary audience, the geotechnical community, which continues to use English units. Additionally, use of metric units would be awkward for certain types of data for which accepted testing standards are in English units. For example, penetration-test data are given in blows per foot. Converting these values to blows per meter would have little meaning to the engineers who must use the data. For these reasons, this report uses English units throughout; metric equivalents are given in parentheses where appropriate. 
Table 1. Data tables comprising a relational database of borehole and well-log data.

Table name

Report

Borehole

Lithology

Penetration test

Sample test

Water level

Seismic velocity

\section{Stored information}

Report number, company, project number, year, maximum borehole depth

Borehole index number, project number, company borehole number, hole type, date drilled, UTM coordinates, collar elevation, total depth

Borehole index number, depth to top of interval, depth to base of interval, text description, twoword lithology, Unified Soil Class, geologic unit

Borehole index number, depth to top of interval, depth to base of interval, blows per foot, sampler diameter, hammer weight, hammer drop distance

Borehole index number, depth to top of sample, depth to base of sample, unit weight, dry density, moisture content, liquid limit, plastic limit, grain size distribution (percent gravel, sand, fines) [data entered as available]

Borehole index number, depth of static water level, date measured, comments

Borehole index number, depth to top of interval, depth to bottom of interval, shear-wave velocity
Current number Of data records

531

4,198

13,042

6,256

1,791

138

Table 2. Status of data entry

\begin{tabular}{lccc}
\hline \multicolumn{1}{c}{ Status } & $\begin{array}{c}\text { Geotechnical } \\
\text { boreholes* }\end{array}$ & $\begin{array}{c}\text { Water } \\
\text { wells }\end{array}$ & Total \\
Located and indexed & 2,786 & 1,412 & 4,198 \\
Lithologic data entered & 741 & 1,343 & 2,084 \\
Penetration data entered & 603 & -- & 603 \\
Sample data entered & 357 & -- & 357 \\
Seismic-velocity data entered & 10 & -- & 10 \\
Static water level entered & 518 & 1,258 & 1,776 \\
\hline
\end{tabular}

\footnotetext{
*Includes test pits, natural exposures, and 63 cone-penetration tests
} 


\section{Map revision}

The geologic map on sheet 1 is based on an existing map (Schmoll and Dobrovolny, 1972a) that has proven reliable in nearly three decades of use by geologists and engineers in the Anchorage area. Four features distinguish my revised map from their original:

(1) Grouping of units. Geotechnical users in the Anchorage area requested a simpler map with fewer geologic units to highlight differences in materials content and gross physical properties that are of engineering significance. Additionally, for the purpose of developing cross sections, it was necessary to reduce the number of surficial-geologic units to those that can also be recognized in the subsurface using only borehole and well logs. As Schmoll and Dobrovolny indicated in their map description, several surficial-geologic units and the contacts between them are difficult to distinguish even in outcrop. Interpreting the subsurface geology is even more troublesome when it must be based almost entirely on small samples described in different ways by geologists, engineers, and water-well drillers. Consequently, I reduced the 16 surficial-geologic units of Schmoll and Dobrovolny to 10 units by using GIS to combine deposits of similar genesis, composition, and age.

(2) Updating of geology. I interpreted 1993 color vertical aerial photographs to update the geologic map, primarily by adding significant artificial-fill deposits that have been emplaced since 1972. These deposits are mostly at Merrill Field airport, Port of Anchorage, and along major new highways. I also recognized a probable landslide deposit in the vicinity of $24^{\text {th }}$ Ave. and Eagle St., along the south bank of Chester Creek valley, which was not included on Schmoll and Dobrovolny's map. This deposit has morphology similar to a landslide deposit about $1 / 2$ mile $(1 \mathrm{~km})$ west as mapped by Schmoll and Dobrovolny. Other than these updates and combining units as described in (1), I did not change their original contacts.

(3) Updating of topographic base map. For the base map, I used U.S. Geological Survey 1:25,000scale topographic maps revised in 1993 and 1994 to portray many new roads and buildings that did not exist at the time of the 1971 revisions used on Schmoll \& Dobrovolny's map.

(4) 30-ft isopach of Bootlegger Cove clay. I inspected about 300 borehole logs to identify those in which soft, fine-grained deposits of Bootlegger Cove Formation (BCF) have a continuous or nearly continuous thickness of $30 \mathrm{ft}(10 \mathrm{~m})$ or more. Soft, fine-grained deposits are here defined as clay, silty clay, clayey silt, silt, and fine sandy silt in which standard penetration test blowcounts are generally less than about 30 per foot. In engineering usage, this corresponds to fine-grained soils with very soft to very stiff consistency (Lambe and Whitman, 1969, p. 77). In boreholes lacking penetration data, deposits are included if predominantly clay but excluded if predominantly silt or sand. The broken, hachured line on sheet 1 shows the approximate position of the $30-\mathrm{ft}$ isopach, with hachures in the direction of increasing thickness. This line marks the approximate boundary of the deep basin in which these fine-grained sediments accumulated. There are numerous exceptions on both sides of the isopach, including boreholes that locally indicate the presence of isolated basins of BCF clay.

\section{Cross-section development}

I selected seven cross-section lines on the basis of (1) optimum orientation and spacing for depicting subsurface geology in the study area, (2) proximity to as many boreholes and water wells as possible, and (3) linear routes familiar to the user community (sheet 1). With one exception (NW/SE section), all of the cross sections are approximately aligned with major roads. Many geotechnical boreholes are drilled for transportation development, particularly at bridge abutments, so road alignments provide optimum corridors for geologic cross sections. The NW/SE section provides a 
cross section from downtown Anchorage to the Chugach mountain front that is also generally perpendicular to topographic contours and geologic trends.

Because the boreholes and water wells are randomly distributed and because there are many areas outside downtown where holes are sparse, logs must be projected laterally to the plane of the cross sections. The selection areas in which borehole logs were projected to specific cross-section lines are shown on sheet 1 . Projecting borehole logs allows the cross sections to represent the topographic profile and subsurface geology along straight lines rather than with jogs to meet selected boreholes. However, among other factors to be discussed, this leads to generalization of the geology because of considerable geologic variation that is typical over the width of the selection corridor. Care must taken to allow for this variation when interpreting the geology in cross section. In the cross sections displayed on sheet 2, the geology at the surface remains true to the map on sheet 1 despite the interpretation of surficial-geologic units in projected borehole logs. In the interpretation of subsurface geology, I incorporated, to the extent possible, likely variations across the selection corridor as well as along the section.

To ensure that borehole logs are projected to cross-section lines in their correct positions, I performed extensive verification of their reported locations and collar elevations. Upon digitizing their locations, boreholes with no reported collar elevations were initially assigned an elevation interpolated from USGS topographic maps. Using GIS, I compared the recorded collar elevations of all boreholes and water-wells to the 1:25,000-scale Digital Elevation Model (DEM). Significant differences may be the result of erroneous recording of the elevation or location, or the result of major cut or fill that was performed between the date of drilling and the date of the topographic map upon which the DEM was developed. In the latter case, if the borehole was drilled before major cut or fill, I checked the recorded elevation for consistency with the previous topography, adjusting if necessary. I compared the recorded elevations of all other holes to the DEM and corrected them to the DEM elevation if in disagreement by more than $10 \mathrm{ft}$. Although by specification the DEM can be in error by as much as one-half the contour interval, this correction procedure ensures that the projected borehole logs are in proper visual relationship to the topographic profile, which is derived from the DEM.

Knowledge of the depth to pre-Quaternary deposits or bedrock is important for seismic and hydrogeologic studies 4 . Except in southeastern Anchorage along the mountain front where bedrock is shallow, there are insufficient boreholes and water wells penetrating bedrock in the selection areas (sheet 1 ) to identify this contact reliably on the cross sections. However, there are enough deep holes scattered around Anchorage to allow approximation of a generalized bedrock surface across nearly the entire study area. Using software operating within GIS, I generated a gridded model of the bedrock surface by interpolating the elevations of bedrock contacts in all boreholes that penetrate bedrock. It was necessary to also take into account that this modeled surface cannot extend any higher than the topographic surface nor intersect boreholes that do not show bedrock. I used grid analysis to limit the upward extent of the modeled bedrock surface by two other gridded surfaces, one representing the topography (DEM), the other representing the bases of all boreholes that do not penetrate bedrock (the depth of bedrock below these boreholes is unknown). The resulting threedimensional bedrock-surface model and DEM make it possible to generate profiles of both the topography and bedrock surface along any desired section. Bedrock-surface profiles shown on all

\footnotetext{
${ }^{1}$ In this report, bedrock refers to all materials underlying Quaternary sediments. Lithologic descriptions given in borehole and water-well logs are insufficient for differentiating bedrock lithologies. In most cases, only "rock" or "bedrock" is given. In the map area, bedrock exposures along the Chugach Mountains are almost exclusively Mesozoic metasedimentary and metavolcanic rocks of the McHugh Complex (Clark and others, 1976). Near the break in slope at the foot of the mountains is the inferred location of the Border Ranges fault zone, which is buried beneath Quaternary sediments. The fault zone is roughly the eastern margin of a Tertiary sedimentary basin in which carbonaceous siltstone, sandstone, and conglomerate of the Kenai Group thicken westward to as much as 5,000 ft beneath Anchorage (Kirshner and Lyon, 1973). It is not possible with available borehole data to delineate the contact between metamorphic and sedimentary rocks beneath the Quaternary sediments.
} 
seven cross sections originated in this way, but have undergone minor manual adjustments to remove artifacts of the computerized interpolation process.

Graphic depictions of the borehole and water-well lithologic logs provided the visual basis for interpreting Quaternary stratigraphy. The graphic logs were produced automatically for selected boreholes using software integrated with GIS. For detailed inspection and comparison of boreholes, I used three-part logs that depict the materials description, geologic unit, and penetration data (fig. 2). Because drillers generally do not interpret geologic units and may describe either multiple detailed layers or a single layer in a unit, grouping layers into interpreted geologic units became an important tool for stratigraphic correlation. For stratigraphic interpretation, I used GIS to display only the geologic-unit logs according to their projected locations and elevations (fig. 3). On sheet 2, vertical lines show the positions of boreholes used to develop the final cross sections.

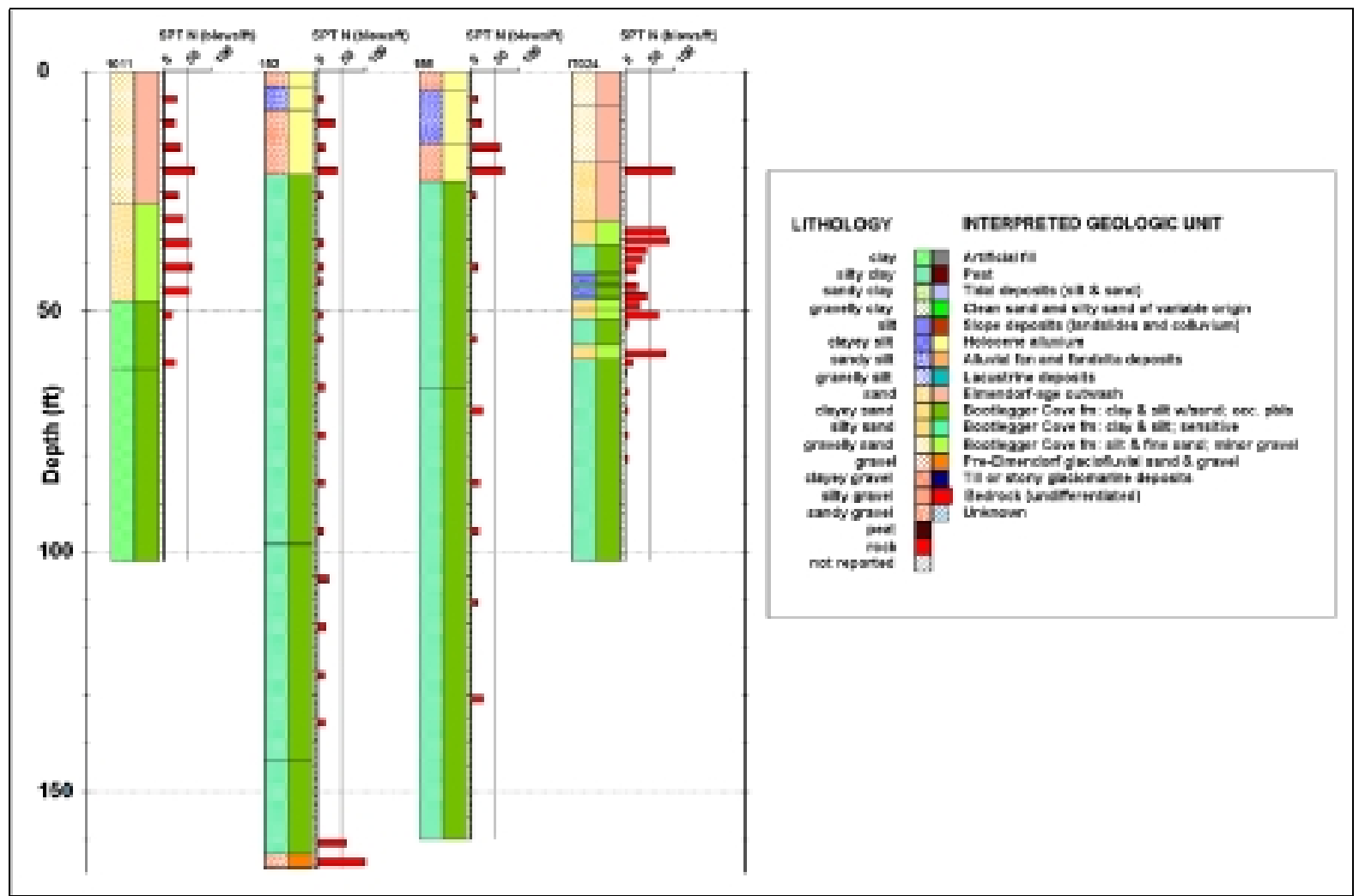

Figure 2. Examples of lithologic logs from boreholes in downtown Anchorage and key to symbols and colors for all logs. Left side of log represents material description; right side represents interpreted geologic unit. Note: Standard penetration test (SPT) data are not available for water wells nor for about $20 \%$ of geotechnicalborehole data entered.

The ability to identify and correlate subsurface units is limited by the highly variable glacial geology, sparseness of deep boreholes, and significant variation in methods and quality of descriptions among dozens of drillers. Rather than force interpretation of detailed, interfingering stratigraphic units where there are insufficient data, I chose to generalize some units so that the correlation would be supportable and as consistent as possible throughout the map area. Although this results in several undifferentiated geologic units, the differences among them appear to be of the level desired by the user community for highlighting engineering and seismic behavior.

Beneath downtown Anchorage, borehole logs reveal relatively straightforward stratigraphy (fig. 3). Boreholes are spaced closely enough in this area to trace most geologic variation. However, in most other areas, subsurface geology is not only more complex, but boreholes are fewer and 
shallower. As a result, the stratigraphy may show no apparent correlation among adjacent boreholes; deep boreholes may be considerable distances apart. Further complicating this picture is the necessity of projecting some boreholes from one-half mile $(\sim 1 \mathrm{~km})$ or more either side of the cross-section line. Most affected by these limitations is the differentiation of till, glaciofluvial, and glaciomarine deposits in the unit mapped as GD (glacial drift). Individual layers within this unit can be locally traced for short distances, but it is not possible to delineate them consistently throughout the map area. Schmoll and Barnwell (1984) identified in a single east-west cross section what they interpreted to be a sequence of seven couplets of till and glaciofluvial deposits representing seven glacial advances and retreats. However, none of the cross-sections I inspected for this study revealed a similar sequence. Consequently, until sufficiently detailed deep borehole logs area available throughout the city, I find it necessary to lump these deposits into a single glacial-drift unit.

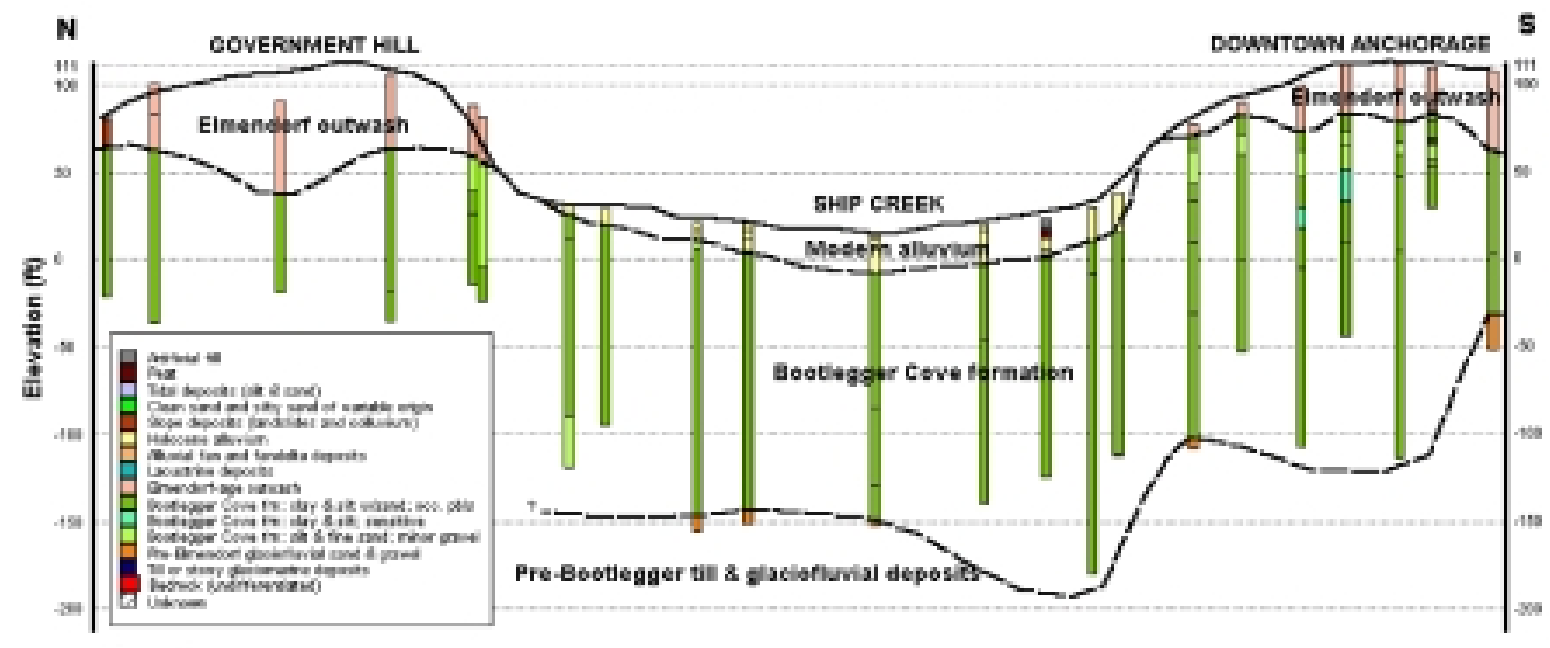

Figure 3. Example of preliminary stratigraphic interpretation based on projected borehole and water-well logs. The tops of some borehole logs do not match the topographic profile along the cross section because these logs are projected from locations where the surface elevation is higher or lower than along the crosssection line.

Many small surficial-geologic units are depicted on the cross sections with little or no borehole control. These deposits are inferred from the geologic map and include primarily colluvium, landslide deposits, artificial fill, and alluvium. Depth to the base of these units is approximate on the cross sections.

\section{DESCRIPTION OF GEOLOGIC UNITS}

F ARTIFICIAL FILL - Loose to dense mixtures of gravel, sand, and silt in variable proportions. Locally contains organic material. Includes all of unit $f$ of Schmoll and Dobrovolny (1972a) and major fill deposits emplaced since 1972.

TS TIDAL DEPOSITS - Moderately to well-sorted fine sand and silt in the modern intertidal zone. Includes only those deposits of unit $s$ of Schmoll and Dobrovolny (1972a) that are of intertidal origin.

AL HOLOCENE ALLUVIUM - Dominantly loose, well-bedded, and well-sorted sand and gravel with negligible to some silt deposited in active and abandoned stream channels and terraces. Same as unit al of Schmoll and Dobrovolny (1972a). 
LS LANDSLIDE DEPOSITS - Deposits that have been deformed or displaced by sliding. These deposits are mostly the result of earthquake-induced translational slides along bluffs where soft silty clay and clayey silt (SC) are overlain by sand and gravel (GF). Density and heterogeneity depend on extent and complexity of sliding. Same as unit $l s$ of Schmoll and Dobrovolny (1972a).

C COLLUVIUM - Slope deposits formed by gravity accumulation of loose, upslope material and consisting of heterogeneous mixtures of gravel, sand, and silt; locally contains some clay. In mountain areas, these deposits are commonly thin (less than several feet thick) and contain angular pebbles and cobbles derived from underlying bedrock. Contact with bedrock (B) is approximate. Same as unit $c$ of Schmoll and Dobrovolny (1972a).

GF GLACIOFLUVIAL, GLACIODELTAIC, AND ALLUVIAL-FAN DEPOSITS Dominantly sand and gravel deposited by high-energy streams emanating from mountain valleys, former nearby glaciers, or stagnant glacial ice. Generally well bedded and well sorted, but locally contains minor silt and clay. Includes Elmendorf-age outwash in downtown Anchorage area (marked by stippled pattern on sheets 1 and 2). Grades from medium to coarse sandy gravel near source areas to gravelly sand and sand at distal margins. May grade imperceptibly into adjacent deposits of C, SS, and GD. Commonly overlain by up to several feet of silt. Includes units an, af, and $g a$ of Schmoll and Dobrovolny (1972a).

SS SILT AND FINE SAND OF GLACIOESTUARINE OR EOLIAN ORIGIN - Dominantly silt, fine sandy silt, and silty fine sand. Locally contains medium to coarse sand and scattered pebbles. Commonly dense to very dense where buried. Contacts with adjacent units are obscure and approximate. Includes noncohesive fine-grained facies of Bootlegger Cove formation (units $s l$, sh, and non-tidal $s$ of Schmoll and Dobrovolny, 1972a).

SC SILT AND CLAY OF GLACIOESTUARINE OR LACUSTRINE ORIGIN - Clay, clayey silt, and silty clay with scattered pebbles, scattered layers of silt and fine sand, and rare cobbles. Consistency ranges from very soft to stiff. Includes lake deposits and cohesive facies of the glacioestuarine Bootlegger Cove formation (units $l$ and $b c$ of Schmoll and Dobrovolny, 1972a, respectively). The cohesive facies of BCF is distinguished by a lined pattern on sheets 1 and 2 .

SCs ZONE OF SOFT, LOCALLY SENSITIVE CLAY AND SILTY CLAY - Sensitive clay facies of Bootlegger Cove formation. Generally very soft to firm. Failure surfaces of most 1964 earthquake-induced slides were in this zone. Appears in cross section only.

GFo OLDER GLACIOFLUVIAL, GLACIODELTAIC, AND ALLUVIAL FAN DEPOSITS Similar to GF except denser due to burial. Appears in cross section only.

GD GLACIAL DRIFT - Heterogeneous, undifferentiated till, stony glaciomarine, glaciolacustrine, and glaciofluvial deposits formed beneath or close to glacial ice. Composition ranges from diamicton to well-sorted sand and gravel and locally includes silt and clay with little or no sand and gravel (subsurface only). Normally dense to very dense. Includes deposits of moraines, drumlins, kames, eskers, and proglacial lakes (units $m$, gm, and $m g$ of Schmoll and Dobrovolny, 1972a). 
B UNDIFFERENTIATED BEDROCK - Metamorphic rocks of Mesozoic age and poorly to well indurated sedimentary deposits of Tertiary age (latter in subsurface only, although not differentiated). Contact interpolated from widely distributed boreholes and water wells. Same as unit $b$ of Schmoll and Dobrovolny (1972a).

\section{CONCLUSIONS}

Borehole and well-log data for Anchorage allow extension of surficial-geologic units into the subsurface and identification and correlation of other subsurface units. The ability to identify and correlate subsurface units is limited by the highly variable glacial geology, sparseness of deep boreholes, and significant variation in methods and quality of descriptions among drillers. Although this results in some generalized, undifferentiated geologic units, the differences among them are of the level desired by the user community for highlighting engineering and seismic behavior.

\section{ACKNOWLEDGMENTS}

This project is an outgrowth of work begun by Randall Updike, who compiled much of the data to get the project started and encouraged its completion. My work benefited greatly from discussions with Updike, Richard Reger, and Henry Schmoll. Reger also provided helpful review comments on this preliminary report. Building the GIS database would not have been possible without the able assistance of student interns Sean Weems and Kelly Sink, microcomputer/network specialist Gina Graham, and geologist DeAnne Pinney. I am grateful for their expert and enthusiastic assistance. Although many organizations provided subsurface data for this project as listed below, I particularly acknowledge the help of David Cole of DOWL Engineers, Jim Rooney and staff of R\&M Consultants, Dan Pavey of the Alaska Department of Transportation \& Public Facilities, Mike Krueger of the Municipality of Anchorage, and Gretta Kooster of the Anchorage School District for the significant time and effort they spent helping me obtain the needed reports.

The following companies and public agencies provided data for this project:

Alaska Department of Transportation \& Public Facilities

Dames \& Moore

DOWL Engineers/Alaska Testlab

Golder Associates

Harding Lawson Associates

Municipality of Anchorage

M-W Drilling

R\&M Consultants

Shannon \& Wilson, Inc.

U.S. Geological Survey Geologic Division

U.S. Geological Survey Water Resources Division

Woodward-Clyde Consultants

This research was partially supported by the U.S. Geological Survey (USGS), Department of the Interior, under USGS award number 1434-HQ-96-GR-02713. The views and conclusions contained in this document are those of the author and should not be interpreted as necessarily representing the official policies, either expressed or implied, of the U.S. Government or State of Alaska. 


\section{REFERENCES CITED}

Cedarstrom, D.J., Trainer, F.W., and Walker, R.M., 1964, Geology and ground-water resources of the Anchorage area, Alaska: U.S. Geological Survey Water Supply Paper 1773, 108 p., 1 sheet, scale $1: 63,360$.

Clark, S.H.B., Yount, M.E., and Bartsch, S.R., 1976, Reconnaissance geologic map and geochemical analyses of stream-sediment and rock samples of the Anchorage A-7 and A-8 quadrangles, Alaska: U.S. Geological Survey Miscellaneous Field Studies Map, MF-765, 3 sheets, scale 1:63,360.

Dobrovolny, Ernest, and Schmoll, H.R., 1974, Slope-stability map of Anchorage and vicinity, Alaska: U.S. Geological Survey Miscellaneous Investigations Map I-787-E, 1 sheet, scale 1:24,000.

Harding-Lawson Associates, 1979, Seismically induced ground-failure susceptibility, Anchorage, Alaska: Alaska Division of Geological \& Geophysical Surveys Miscellaneous Paper 32, 1 sheet, scale 1:25,000 [digitally recompiled with 1993-1994 revised topography by S.M. Weems and R.A. Combellick, 1997].

Kirschner, C.E., and Lyon, C.A., 1973, Stratigraphic and tectonic development of Cook Inlet petroleum province, in Pitcher, M.G., ed., Arctic Geology: American Association of Petroleum Geologists Memoir 19, p. 396407.

Lambe, T.W., and Whitman, R.V., 1969, Soil Mechanics: New York, John Wiley \& Sons, 553 p.

Miller, R.D., and Dobrovolny, Ernest, 1959, Surficial geology of Anchorage and vicinity, Alaska: U.S. Geological Survey Bulletin 1093, 128 p., scale 1:63,360.

Reger, R.D., Combellick, R.A., and Brigham-Grette, Julie, 1995, Late-Wisconsin events in the upper Cook Inlet region, Alaska, in Combellick, R.A., and Tannian, Fran, eds., Short Notes on Alaska Geology 1995: Alaska Division of Geological \& Geophysical Surveys Professional Report 117, p. 33-45.

Schmoll, H.R., and Barnwell, W.W., 1984, East-west geologic cross section along the DeBarr Line, Anchorage, Alaska: U.S. Geological Survey Open-File Report 84-791, 10 p., 1 sheet, scale 1:25,000.

Schmoll, H.R., and Dobrovolny, Ernest, 1972a, Generalized geologic map of Anchorage and vicinity, Alaska: U.S. Geological Survey Miscellaneous Geologic Investigations Map I-787-A, 1 sheet, scale 1:24,000. 1972b, Slope map of Anchorage and vicinity, Alaska: U.S. Geological Survey Miscellaneous Geologic Investigations Map I-787-B, 1 sheet, scale 1:24,000. 1973, Construction materials map of Anchorage and vicinity, Alaska: U.S. Geological Survey Miscellaneous Geologic Investigations Map I-787-C, 1 sheet, scale 1:24,000. 1974, Foundations and excavation conditions map of Anchorage and vicinity, Alaska: U.S. Geological Survey Miscellaneous Geologic Investigations Map I-787-D, 1 sheet, scale 1:24,000.

Schmoll, H.R., and Emanuel, R.P., 1981, Generalized geologic map and hydrologic properties of the Potter Creek area, Municipality of Anchorage, Alaska: U.S. Geological Survey Open-File Report 81-552, 5 p., 1 sheet, scale 1:25,000.

Updike, R.G., and Ulery, C.A., 1986, Engineering-geologic map of southwest Anchorage, Alaska: Alaska Division of Geological \& Geophysical Surveys Professional Report 89, 1 sheet, scale 1:15,840.

Yehle, L.A., Schmoll, H.R., and Dobrovolny, Ernest, 1990, Geologic map of the Anchorage B-8 SE and part of the Anchorage B-8 NE quadrangles, Alaska: U.S. Geological Survey Open-File Report 90-238, 37 p., 2 sheets, scale 1:25,000.

1991, Geologic map of the Anchorage B-8 SW quadrangle, Alaska: U.S. Geological Survey OpenFile Report 91-143, 30 p., 2 sheets, scale 1:25,000.

1992, Surficial geologic map of the Anchorage A-8 SE quadrangle, Alaska: U.S. Geological Survey Open-File Report 92-350, 33 p., 2 sheets, scale 1:25,000. 